\title{
Increasing numbers and intercontinental spread of invasive insects on eucalypts
}

\author{
Brett P. Hurley ${ }^{1,2 *}$, Jeff Garnas ${ }^{1,2}$, Michael J. Wingfield ${ }^{1}$, Manuela Branco ${ }^{3}$, David M. Richardson ${ }^{4}$,
} Bernard Slippers ${ }^{1,5}$

${ }^{1}$ Forestry and Agricultural Biotechnology Institute (FABI), University of Pretoria, Pretoria, 0002, South Africa

${ }^{2}$ Department of Zoology and Entomology, University of Pretoria, Pretoria, 0002, South Africa

${ }^{3}$ Centro de Estudos Florestais (CEF), Instituto Superior de Agronomia, Technical University of Lisbon, Lisbon, Portugal

${ }^{4}$ Centre for Invasion Biology, Department of Botany and Zoology, Stellenbosch University, Matieland 7602, South Africa

${ }^{5}$ Department of Genetics, University of Pretoria, Pretoria, 0002, South Africa

*Corresponding author:

Dr Brett Hurley

brett.hurley@fabi.up.ac.za

Phone: +27 124205822

Fax: +27 124203960

\begin{abstract}
Native to Australasia, Eucalyptus (sensu lato) is one of the most planted genera of trees in the world. However, the sustainability of Eucalyptus species as plantation trees in non-native areas is increasingly threatened by the introduction and spread of Eucalyptus-feeding insects from Australia. We examine patterns and potential trends with respect to the global spread of Eucalyptusfeeding insects. Likely pathways of introduction and drivers of the rapid distribution of these insects, as well as management options are considered. The rate of introductions is shown to have increased nearly fivefold since the 1980s. As a result, the number of non-native pests of eucalypts outside of Australia has doubled in less than three decades. Furthermore, the rate of secondary spread among continents has also increased. Surprisingly, we found no association between area planted and the number of pests or new introductions. Only a small number of countries have been the points of first detection outside the native range; these countries have acted as bridgeheads to other regions.

Quarantine regulations aimed at reducing the spread of invasive organisms appear to be ineffective at a global scale, and pathways allowing these invasions to occur are poorly understood or unknown. An expanded suite of management options are needed to provide resilience against the rapid accrual and homogenization of eucalypt pests, thereby ensuring the sustainability of eucalypt forestry worldwide.
\end{abstract}

Keywords: Biological invasions, Eucalyptus, bridgehead effect, pathway management, forestry, pest homogenization 


\section{Introduction}

Biological invasions pose one of the greatest threats to global biodiversity as well as to the sustainable production of food and fibre for the needs of a growing world population (Pimental et al. 2001; Wingfield et al. 2008; Flood 2010; Wingfield et al. 2011; Bebber et al. 2014a). Crops that have been planted outside their native range are particularly vulnerable to such invasions. Many of these crops were likely initially free of diseases and herbivores which permitted rapid growth and high yields (Jeffries and Lawton 1984; Keane and Crawley 2002). However, over time a number of insects and pathogens from the native regions of cultivated species have been moved around the world, generally accidentally, and have become established in the new ranges of their plant hosts. In many cases, these invaders have become pests in their new environment, in part because of the increased economic value associated with their host plants in these areas. But this has also been due to the large uninterrupted areas of host material available, a lack of host resistance and the absence of their own complement of natural enemies. The increasing rate at which these invasive species are becoming established represents a considerable threat to the sustainable production of many crop species (Fisher et al. 2012; Bebber et al. 2014a; Roy et al. 2014). Managing this threat to prevent future pest accrual will require knowledge on the patterns and mechanisms of movement (“dispersal pathways” sensu Wilson et al. (2009)). Such insights are also crucial for informing management responses to combat those pests that do establish and spread. There is accumulating evidence that the existence of discrete, globally distributed invasive populations can have important ecological and evolutionary consequences (Garnas et al. 2016; this issue).

This review examines patterns and potential trends associated with the global spread of herbivorous insects. Likely pathways of introduction and drivers of rapid spread are considered, as are options for managing these pests. Eucalypts provide an example of a suite of closely-related plant species of global economic importance, planted extensively outside their native range, and which have become increasingly threatened by invasive phytophagous insects (Wingfield et al. 2008; Paine et al. 2011; Brockerhoff et al. 2013). We further consider how the globalization of this crop taxon has influenced and has been influenced by invasive pest species. Specifically, we examine the global movement of eucalypt-feeding insects native to Australia that have become pests in their new ranges. How these patterns of invasion have changed over time and what they reveal about possible pathways of introduction are considered. In addition, some of the critical changes required in our response to these invasions in order to manage the threat they pose to eucalypt forestry are discussed.

\section{Past, present and future of eucalypt forestry}

Eucalypts (taxa in the closely-related genera Eucalyptus, Corymbia and Angophora in the Myrtaceae) are currently among the most widely planted tree species in the world, second only to pines (Pinus spp.) (Rejmánek and Richardson 2011). These trees are now grown in all continents where conditions permit (i.e., excluding Antarctica), mostly in the tropical and temperate climatic zones between $45^{\circ} \mathrm{S}$ and $40^{\circ} \mathrm{N}$ as well as other regions where local climates are suitable for growth (Eldridge 
et al. 1994). Most eucalypts are fast-growing trees, and can establish and grow well across a wide range of environmental conditions, including those where water is limited. Historically they were planted primarily for timber, shade and fuel, properties that have led to their widespread planting by European colonists as they moved around the world. For example, in 1828 E. globulus (commonly known as blue gum) was introduced into the Cape Colony in South Africa and by 1883 at least 14 Eucalyptus species had been planted in that country (Olivier 2010). Today, eucalypts are planted as ornamentals, as sources of essential oils and as foliage for the cut-flower industry, and have become increasingly important in the global fibre market (Turnbull 1999).

The area planted to eucalypts worldwide has increased dramatically since these trees were first planted outside their native range. By 1985, the total area planted to eucalypts was estimated at 6 million hectares (Eldridge et al. 1994). By 2008 the area had increased to nearly 20 million hectares (FAO 2010; Brockerhoff et al. 2013). Most of the increase in planted land over this period has been due to the expansion of planting in India (550 000 ha to near 4 million ha), Brazil (2.5 million ha to 3.7 million ha) and China (300 000 ha to 2.6 million ha); these countries are currently the major growers of eucalypts in the world (Eldridge et al. 1994; Iglesias-Trabado and Wilstermann 2008). Today, a large number of eucalypt species (mainly Eucalyptus spp.) are planted outside Australia, with the dominant species being E. grandis, E. globulus, E. nitens, E. camaldulensis and E. tereticornis (FAO 2006; Rejmánek and Richardson 2011). In some countries (Spain, Portugal and Chile, for example), Eucalyptus plantations are dominated by one or two species; commonly E. globulus. In countries that have invested heavily in Eucalyptus planting on an industrial scale and where these trees are planted across large, heterogeneous areas (i.e., South Africa and Brazil), plantations consist of numerous different species and hybrids.

Together with silviculture and site-species matching, tree breeding is one of the main options to increase the productivity of eucalypt plantations. The early introduction of eucalypts outside their native range mostly involved collection and planting of seeds from unknown provenances (Olivier 2010). Later, provenance trials were established to improve environmental matching of tree populations with local conditions (Eldridge et al. 1994; Grattapaglia and Kirst 2008). Later breeding methods came to include hybridization of species possessing complementary, desirable traits, followed by vegetative propagation (“cloning”) to multiply individuals of a particular cross. Most recently, opportunities to plant genetically modified Eucalyptus have been explored, with the first commercial plantings approved by Brazil in 2015 (http://www.b3cnewswire.com/201504101194/futurageneseucalyptus-is-approved-for-commercial-use-in-brazil.html; accessed June 2015), although the use of genetically modified organisms is still prohibited by some certification organizations such as the Forest Stewardship Council (FSC). Regardless of the method used, the focus of eucalypt breeding has been to increase yields and to improve wood quality for various end uses. In addition, breeding for resistance to some diseases (e.g. Cryphonectria canker; see Wingfield (2003)) has been highly successful.

Resistance breeding, however, is a constantly shifting target because new pests and pathogens continue to emerge and those already present adapt to infest/infect new planting stock. 


\section{Changing patterns of pest invasion}

Early eucalypt forestry outside the native range of these trees benefited from a largely pestfree environment (Wingfield et al. 2008). However, over time, numerous insects that feed on these trees have arrived in areas where the trees are propagated commercially. The pathways that have facilitated these introductions are poorly known. As with their hosts, these insects mostly arrived without their natural enemies, a factor that has most likely contributed substantially to their success. The first reported insect pest of eucalypts was the Eucalyptus longhorn beetle Phoracantha semipunctata, reported in New Zealand in 1873 (Withers 2001). This was followed by Ctenarytaina eucalypti and Gonipterus scutellatus, now known to be a species complex comprising three different

Fig. 1. Cumulative introduction of insect pests feeding on eucalypts outside their native range in Australasia. Symbols

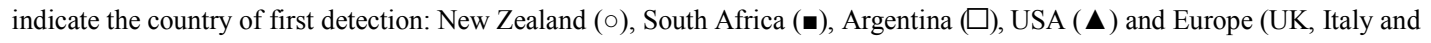
France; •). Dashed line shows log-linear regression model, where $\ln$ (cumulative introductions) $=-35.9+0.02 *$ Year. Solid line shows piecewise regression model, where slope $1=0.16$, slope $2=0.74$ and breakpoint $=1986$. The rate of introduction of new pests has increased substantially since 1986 .

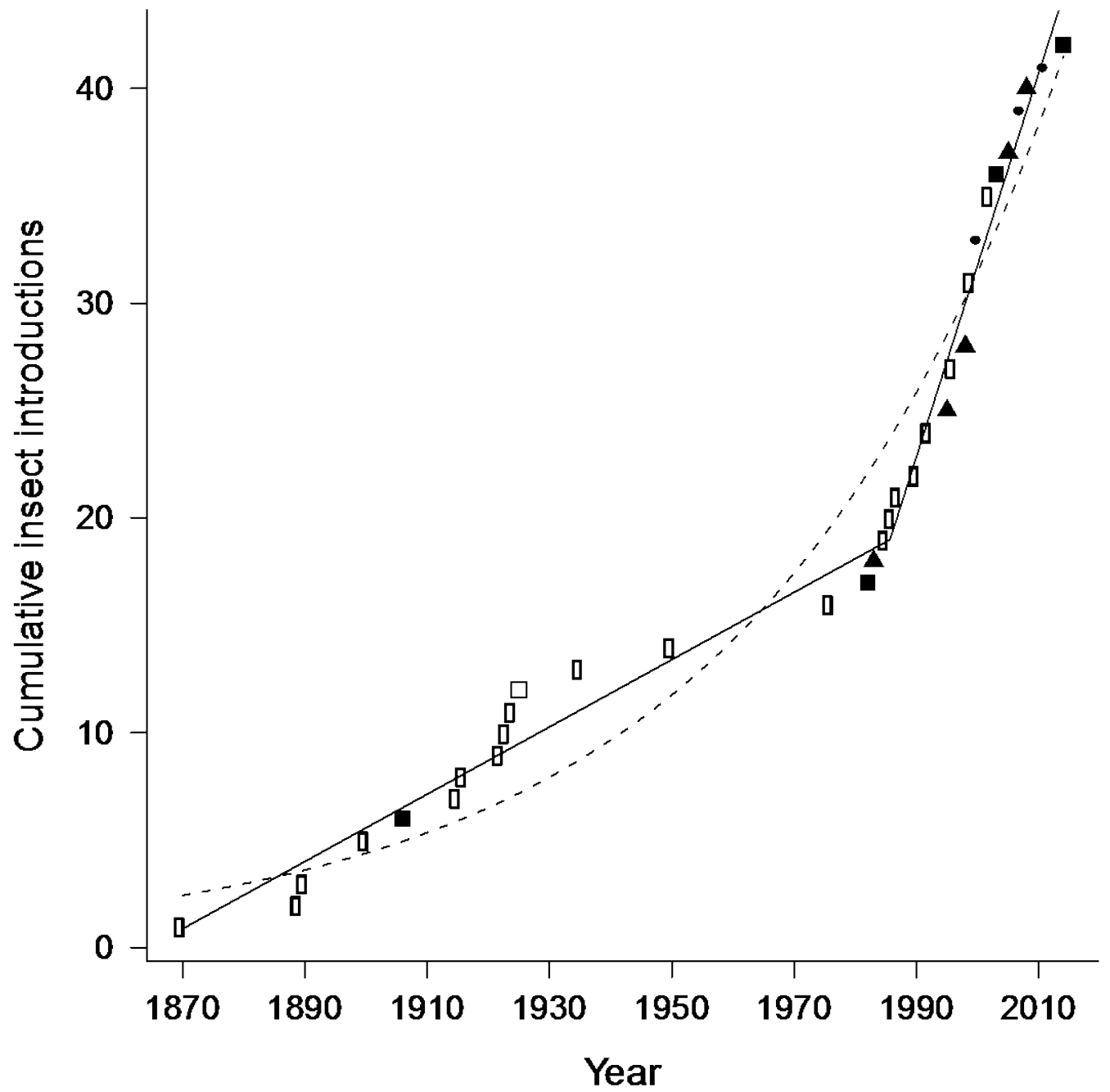


species (Mapondera et al. 2012), both detected in New Zealand, in 1889 and 1890, respectively (Withers 2001). Eucalypt-feeding insects continued to appear in New Zealand and other regions where these trees are non-native at a rate of approximately 0.16 insect species per year that were detected outside their native range for the first time (or one insect species every 6.3 years) from 1873-1986 (Figure 1). However, from 1986 to 2014 there has been a sharp increase in the rate of introductions with an average of 0.74 insect species per year that were detected outside their native range for the first time (or one insect species every 1.4 years) (Figure 1). The substantial increase in the rate of invasion after 1986 coincides with an increase of the area of eucalypts forest plantations which increased by 90\% since the fifties, and about 50\% since 1990 (Turnbull 1999). The increase in the rate of invasion also corresponds to the Uruguay Round negotiations (1986-1994), which forms much of the legal framework of the World Trade Organization (WTO) and assisted to open markets for trade (www.wto.org; accessed October 2015). The widespread increase of eucalypts plantations and increased trade might have contributed to the increased dispersal pathways from the endemic range as well as movement from beachheads.

The total number of eucalypt pest insects originating in Australia and introduced to other parts of the world varies depending on which insects are classified as pests, but the most recent estimate cites 37 insects (Nahrung, Swain, 2015). This list did not include Ctenarytaina longicauda that was detected in the USA in 1983 (Paine et al. 2010), Ophelimus sp. detected in Europe in 2011 (Borowiec et al. 2012), or Spondyliaspis c.f. plicatuloides detected in South Africa in 2014 (Samantha Bush, unpublished). In addition, Nahrung and Swain (2015) listed the Gonipterus scutellatus complex and not the three Gonipterus species as described by Mapondera et al. (2012). These changes have been included in Table 1, which lists a total of 42 pest introductions. Two further species, Paropsisterna beata and Phellopsylla formicosa, were first detected in New Zealand in 2012 and 2014, respectively (www.biosecurity.govt.nz/pests/eucalyptus-leaf-beetle; naturewatch.org.nz/observations/986762). However, these two species are not yet confirmed as established pests on eucalypts. This list excludes seed- and flower-feeding insects and insects where eucalypts are not the main host.

Introduced pest insects of eucalypts represent a number of different taxonomic groups and feeding types. In total, 16 different families have been introduced with Hemiptera being the dominant order (17 species), followed by Coleoptera (12), Hymenoptera (8) and Lepidoptera (5) (Table 1, Figure 2). Most of the introduced insects have been sap-sucking taxa (17 species), mainly Psyllidae, followed by defoliators (13) and gall formers (7). There have been only three introductions of wood-boring insects; all three species were first detected outside Australia in New Zealand, the last being in 1935. Two of these wood-boring species subsequently spread to other regions of the world (Phoracantha recurva and $P$. semipunctata). There have been no further introductions of eucalypt wood-boring insects from Australia over the last 80 years, this despite the presence of important wood-boring pests in Australia (e.g., Phoracantha acanthocera, P. solida, P. mastersi and Endoxyla spp. (Wylie and Peters 1993; Farr et al. 2000; Lawson et al. 2002; Nahrung and Swain 2015). Only two leaf miners have been introduced outside of Australia; both to New Zealand, but neither has been found on other continents. Likewise, four lepidopteran defoliators of eucalypts, native to Australia, are recorded as exotics only in New Zealand. 
Table 1. List of known eucalypt insect pests introduced between 1870-2014 outside their native range, namely Africa (A), Asia (As), Australasia (Au, referring to New Zealand), Europe (E), North America (NA) and South America (SA).

\begin{tabular}{|c|c|c|c|c|c|}
\hline Insect & Family & Order & Feeding & Imasion history & $\begin{array}{l}\text { Date of first } \\
\text { introduction }\end{array}$ \\
\hline Phoracantha semipunctata & Cerambycidae & Coleoptera & Wood borer & $A, A u, E, N A, S A$ & 1870 \\
\hline Ctenarytaina ewcalypti & Psyllidae & Hemiptera & Sap-sucker & A, As, Au, E, NA, SA & 1889 \\
\hline Gonipterus pkatensis & Curculionidae & Coleoptera & Defoliator & $\mathrm{Au}, \mathrm{E}, \mathrm{NA}, \mathrm{SA}$ & 1890 \\
\hline Eriococcus coniaceus & Eriococcidae & Hemiptera & Sap-sucker & $\mathrm{Au}$ & 1900 \\
\hline Paropsis charybidis & Chrysomelidae & Coleoptera & Defoliator & Au & 1900 \\
\hline Phoracantha recurva & Cerambycidae & Coleoptera & Wood borer & $A, E, N A, S A$ & 1906 \\
\hline Opodiphthera excalypti & Saturniidae & Lepidoptera & Defoliator & $\mathrm{Au}$ & 1915 \\
\hline Gonipterus sp.2 & Curculionidae & Coleoptera & Defoliator & $A, E$ & 1916 \\
\hline lepidosaphes eucalypti & Diaspididae & Hemiptera & Sap-sucker & Au & 1922 \\
\hline Strepsicrates macropetana & Tortricidae & Lepidoptera & Defoliator & $\mathrm{Au}$ & 1923 \\
\hline Strepsicrates infensa & Tortricidae & Lepidoptera & Defoliator & Au & 1924 \\
\hline Gonipterus pulverulentus & Curculionidae & Coleoptera & Defoliator & SA & 1925 \\
\hline Callidiopsis scutellaris & Cerambycidae & Coleoptera & Wood borer & $\mathrm{Au}$ & 1935 \\
\hline Aleuroclava excalypti & Aleyrodidae & Hemiptera & Sap-sucker & Au & 1950 \\
\hline Blastopsylla occidentalis & Psyllidae & Hemiptera & Sap-sucker & $A, E, N A, S A$ & 1976 \\
\hline Trachymela skanei & Chrysomelidae & Coleoptera & Defoliator & NA & 1976 \\
\hline Trachymela tincticollis & Chrysomelidae & Coleoptera & Defoliator & $\mathbf{A}$ & 1982 \\
\hline Ctenarytaina longicauda & Psyllidae & Hemiptera & Sap-sucker & NA & 1983 \\
\hline Phylacteophaga froggati & Pergidae & Hymenoptera & Leaf miner & $\mathrm{Au}$ & 1985 \\
\hline Glycaspis granulata & Psyllidae & Hemiptera & Sap-sucker & Au & 1986 \\
\hline Ophedimus excalyptii & Eulophidae & Hymenoptera & Gall-former & Au & 1987 \\
\hline Ctenarytaina spatukata & Psyllidae & Hemiptera & Sap-sucker & $E, N A, S A$ & 1990 \\
\hline Trachymela catenata & Chrysomelidae & Coleoptera & Defoliator & $\mathrm{Au}$ & 1992 \\
\hline Uraba lugens & Noctuidae & Lepidoptera & Defoliator & Au & 1992 \\
\hline Ctenarytaina triangular & Psyllidae & Hemiptera & Sap-sucker & NA & 1995 \\
\hline Cardiaspina fiscella & Psyllidae & Hemiptera & Sap-sucker & Au & 1996 \\
\hline Eucalyptoma maideni & Psyllidae & Hemiptera & Sap-sucker & NA & 1996 \\
\hline Glycaspis brimblecombei & Psyllidae & Hemiptera & Sap-sucker & $A, E, N A, S A$ & 1998 \\
\hline Acrocercops kaciniella & Gracillariidae & Lepidoptera & Leaf miner & $\mathrm{Au}$ & 1999 \\
\hline Epichrysocharis burwelfi & Eulophidae & Hymenoptera & Gall-former & As, NA, SA & 1999 \\
\hline Nambouria xanthops & Pteromalidae & Hymenoptera & Gall-former & Au & 1999 \\
\hline Leptocybe invasa & Eulophidae & Hymenoptera & Gall-former & $A, A s, E, N A, S A$ & 2000 \\
\hline Ophefimus maskelfi & Hymenoptera & Hymenoptera & Gall-former & $\mathrm{A}, \mathrm{As}, \mathrm{E}, \mathrm{NA}$ & 2000 \\
\hline Anoeconeossa communis & Psyllidae & Hemiptera & Sap-sucker & Au & 2002 \\
\hline Creiis fituratus & Psyllidae & Hemiptera & Sap-sucker & Au & 2002 \\
\hline Thaumastocoris peregrinus & Thaumastocorid: & Hemiptera & Sap-sucker & $A, A u, E, S A$ & 2003 \\
\hline Trachymela m-fuscum & Chrysomelidae & Coleoptera & Defoliator & NA & 2005 \\
\hline Ctenarytaina peregrina & Psyllidae & Hemiptera & Sap-sucker & $\mathbf{E}$ & 2007 \\
\hline Paropsistema gloriosa & Chrysomelidae & Coleoptera & Defoliator & $\mathrm{E}$ & 2007 \\
\hline Selitrichodes globulus & Eulophidae & Hymenoptera & Gall-former & NA & 2008 \\
\hline Ophelimus sp. & Eulophidae & Hymenoptera & Gall-former & $\mathrm{E}$ & 2011 \\
\hline Spondyliaspis cf. plicatulo & s Psyllidae & Hemiptera & Sap-sucker & A & 2014 \\
\hline
\end{tabular}


Fig. 2. Time required for eucalypt-feeding insects to spread globally. Indicated by the number of years from when they were first reported outside their native range to when they had spread to two continents outside their native range. Data presented for the introductions of Phoracantha semipunctata (first detected outside native range in 1870), Ctenarytaina eucalypti (1889),

Gonipterus platensis (1890), Phoracantha recurva (1906), Blastopsylla occidentalis (1976), Ctenarytaina spatulata (1990), Glycaspis brimblecombei (1998), Leptocybe invasa (2000), Ophelimus maskelli (2000) and Thaumatocoris peregrinus (2003) (see Table 1 for more details of introductions). Insect pests that have been introduced outside their native range since 1970 have taken less time to spread to other continents than insects that were introduced before this period.

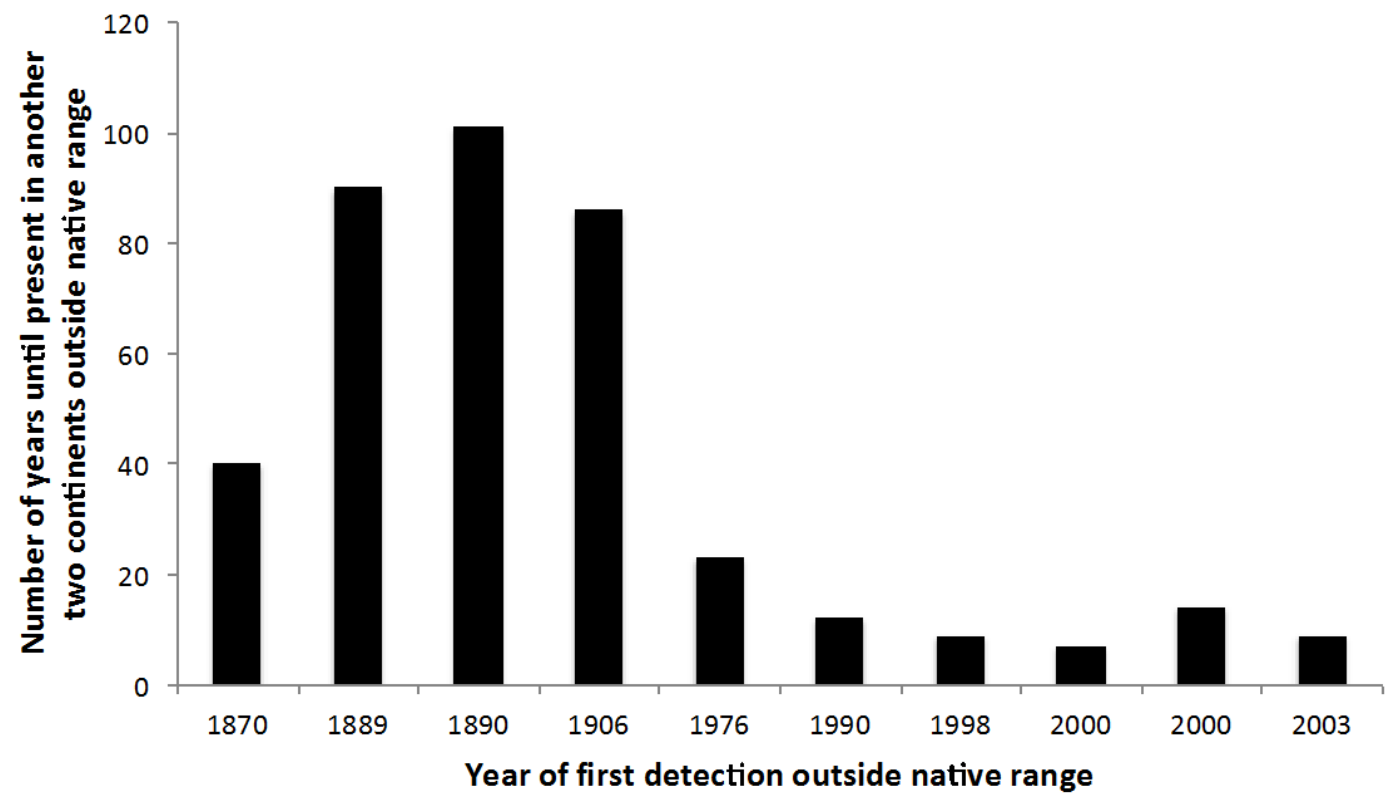

The proportion of insect orders and feeding guilds of eucalypt pest insects in Australia that have become successful invaders outside their native range differs from the eucalypt pest insects in Australia that have not become invasive. A higher proportion of Hemiptera, Hymenoptera, gall-formers and sap-suckers and a lower proportion of Coleoptera, Lepidoptera, wood-borers and defoliators are found amongst the invasive taxa (Strauss 2001; Nahrung and Swain 2015). Nahrung and Swain (2015) also compared the life-history traits of these groups and found that the insects that had become successful invaders in introduced areas were generally those with smaller body size, more generations per year, lower incidence of diapause, longer flight season and that were more closely host associated.

It is generally accepted that when an invasive species becomes established outside its native range, the probability of further spread increases due to the existence of a larger source population. This is a phenomenon referred to by Lombaert et al. (2010) as the invasive bridgehead effect. For most introductions of eucalypt-feeding insects the source of the introduction is not known, but it is likely that the invasive bridgehead effect has influenced the distribution of many of the 12 insect pests of eucalypts outside Australia that have spread to two or more continents since first being reported outside their native range (Table 1). However, only two species, Leptocybe invasa and Ctenarytaina eucalypti, has been confirmed to be present in all six continents where eucalypts are grown. Gonipterus scutellatus was thought to have spread globally (except Asia), but it was later discovered that the 
species had been misidentified and that 'G. scutellatus' represents a complex of at least three species (Mapondera et al. 2012). These include G. platensis found in New Zealand, South and North America and western Europe, G. pulverulentus in South America, and an undescribed species (Gonipterus sp. 2) in Africa and southern Europe.

Fig. 3. Total number of pest insects on eucalypts that have been introduced outside their native range, by insect order and feeding guild. The majority of introduced eucalypt pests are sap-sucking hemipterans.

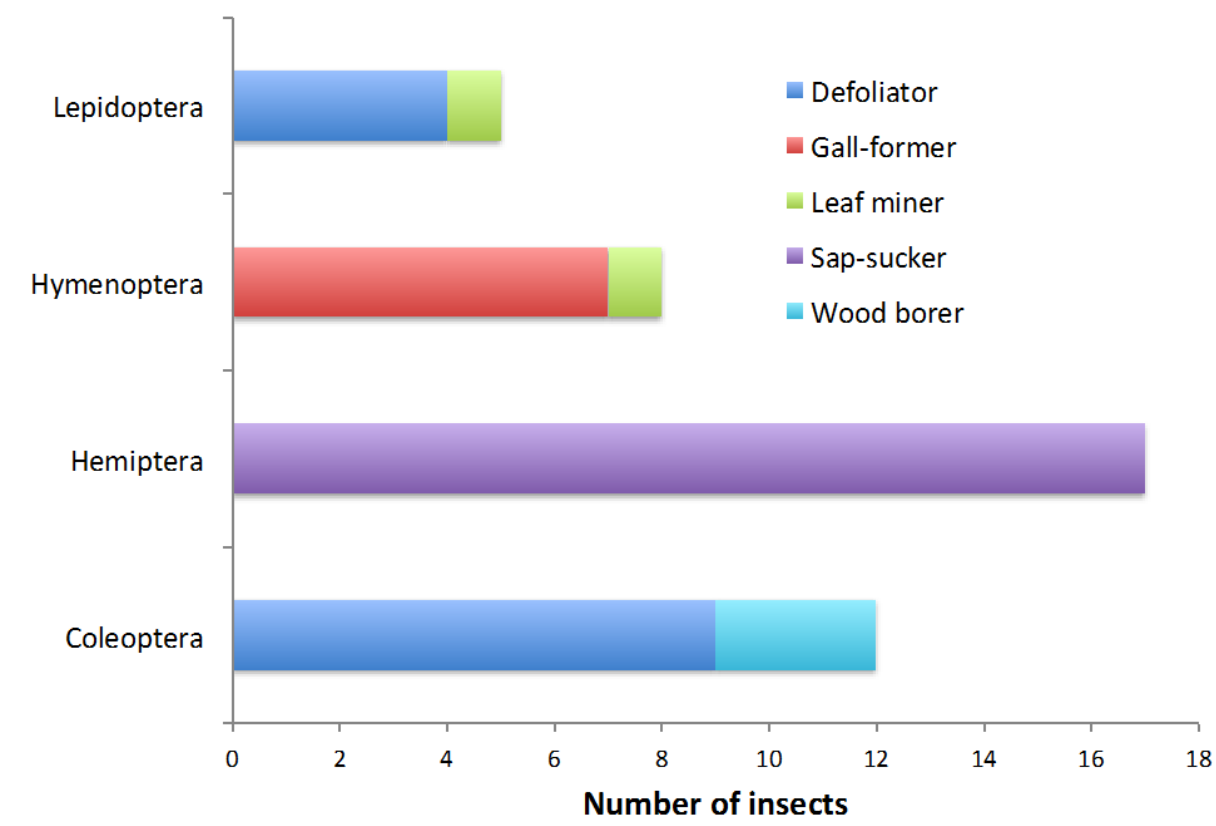

The time required for invasive pest insects of eucalypts to spread between different continents has become shorter in recent decades (Figure 3). For example, Ctenarytaina eucalypti and Phoracantha recurva required over 80 years to spread to a further two new continents subsequent to their first being detected outside their native range. Leptocybe invasa, Thaumastocoris peregrinus and Glycaspis brimblecombei, however, all spread to two or more continents in less than 10 years. Many of these insects are also spreading rapidly within the continents where they have become established. The increased rate at which insects are spreading within and between continents is most likely facilitated by the increase in trade and travel. But it also clearly illustrates the inefficiency of global quarantine measures. This pattern of increasingly rapid globalisation of insect pests and the increase in the emergence of new pests poses a significant threat to eucalypt forestry.

\section{What do patterns of invasion reveal about pathways?}

Records of detection are typically noted by country, though outlying territories belonging to a mainland political entity (e.g., Guam, the Canary Islands, etc.) are often considered separately. Of the vast number of possible introduction points (countries or territories) that could be the first to receive a 
Fig. 4. Proportion of total introduced eucalypt pests and first introduction of eucalypt pests, by continent. Australasia (representing New Zealand) has the highest number of total pests and first introductions, while Asia and South America have the least. Note that the sum of the proportion of total introduced pests for all the continents is greater than one, because many of the insects are present on more than one continent.

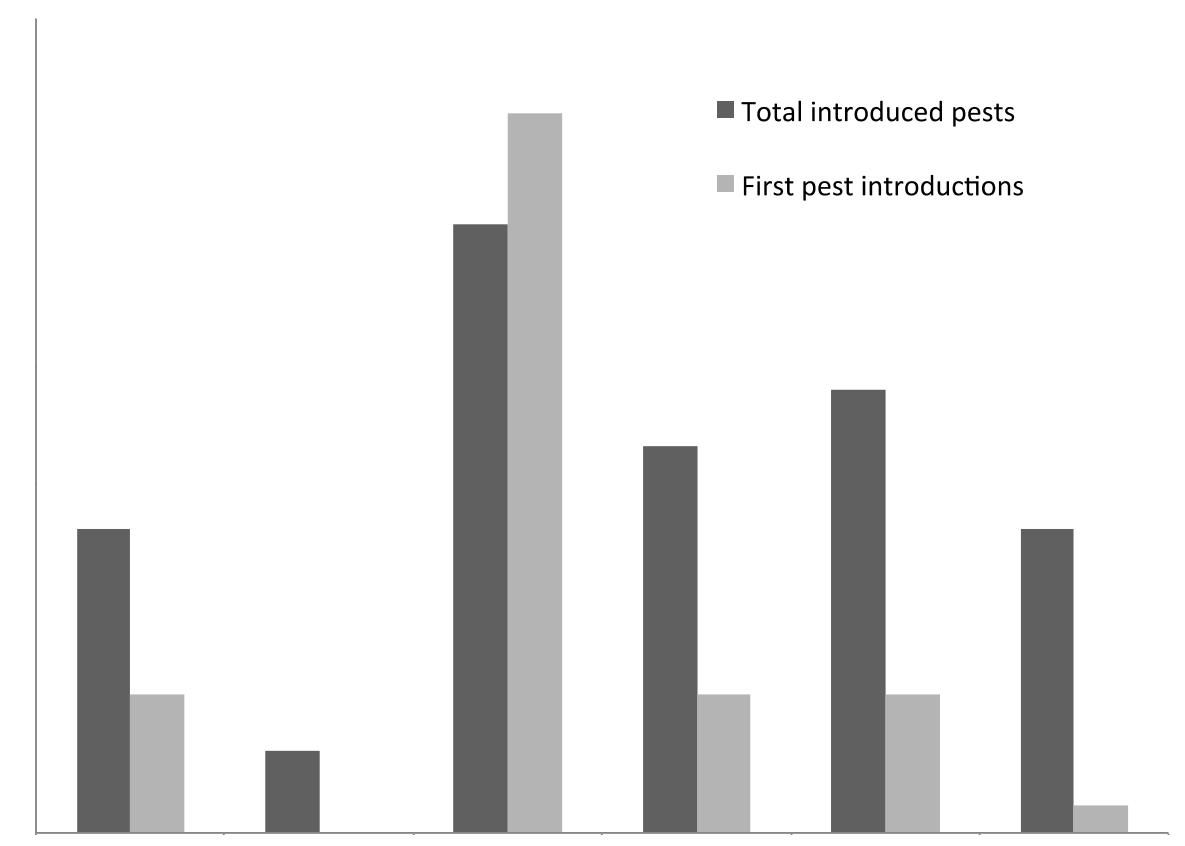

new invader, a few are disproportionately represented in practice. There have been only a small number of entry points (countries) for the first detection of eucalypt pests outside their native range (Figures 1 and 4). The countries where first detections have been reported include Ireland, France, Italy, UK and Israel (Europe-Mediterranean region), New Zealand (Australasia), South Africa (Africa), Argentina (South America), and the USA (North America).

Of all the regions that have been the recipient of 'first detections', New Zealand has had the greatest number of these introductions of Eucalyptus pests from Australia. This country also has the greatest proportion of insect introductions in total (Figure 4). This is not surprising given the close proximity of New Zealand to Australia and the frequent trade between the two countries (Ridley et al. 2000; Withers and Bain 2009). There are also reported incidents of insect introductions from Australia to New Zealand via wind currents crossing the Tasman Straits (Close et al. 1978; Fox 1978). Recently, a greater proportion of first detections have been reported in areas outside of New Zealand, possibly because of an increasing growth of global as opposed to local trade. Interestingly, Withers and Bain (2009) have reported a decrease in insect introductions into New Zealand, possibly associated with a growing understanding of the problem and increasingly stringent biosecurity measures.

Country size is a plausible predictor of the number of insect introductions that might occur. This is due to classical island biogeography, border length with neighboring countries and as a consequence of correlations between land area, population and Gross Domestic Product (GDP; and 
therefore the magnitude of international trade). Surprisingly, however, there is no clear relationship between the land area planted to eucalypts and the number of introductions that have occurred. Most land planted to eucalypts is in Asia and South America; yet there is only one report of a first detection in South America (Gonipterus pulverulentus) and there are none in Asia (Figure 4). The possible presence of two Leptocybe species (Nugnes et al. 2015) may be the first account of a first detection of a eucalypt pest into Asia, but this requires confirmation. South America, and particularly Asia, also has the lowest total number of introduced eucalypt pests.

The lower number of first detections as well as total eucalypt pests in Asia could have been influenced by the relatively recent expansion of eucalypt forestry in that region. In 1985, the period preceding the sharp increase in the rate of insect introductions, the size of the planted area in India was 550000 ha (compared to 4 million by 2008) and in China 300000 ha (compared to 2.6 million by 2008) (Iglesias-Trabado and Wilstermann 2008). If the size of the forestry operation is a determining factor, then a high number of arrivals into Asia could be expected in the near future. However, this reasoning would not explain the situation in Brazil where 2.5 million ha had already been planted by 1985.

The lack of a relationship between planted land and pest introductions is supported by Roy et al. (2014). These authors analysed data for forest insect pest invasions in 21 countries and found no association between forested land and the introduction of invasive forest species. In contrast, the study found forest pest invasions to have a strong relationship with GDP, which they considered to be a useful proxy of overall trade volumes.

Understanding the pathways of insect introductions is an important step towards reducing subsequent invasions (Baker et al. 2005; Hulme 2006; Liebhold et al. 2012; Essl et al. 2015). When dominant routes of entry are known, quarantine and phytosanitary measures can be used more effectively to regulate steps along these pathways (Essl et al. 2015). This then reduces the probability of the introduction and establishment of invasive species, an approach referred to as pathway management (Brockerhoff et al. 2006b; Liebhold 2012; Liebhold et al. 2012; Haack et al. 2014; Roy et al. 2014). Unfortunately, for insect pests of eucalypts, the pathways of introduction are largely unknown. However, by considering known pathways for other forest insects together with the known first entry points of introductions, it is possible to make reasonable assumptions as to likely pathways of invasion of eucalypt pests.

For forest insect pests in general, two of the most common pathways of introduction are untreated wood products (Brockerhoff et al. 2006a; Haack 2006; Skarpaas and Økland 2009) and live plant material (Kenis et al. 2007; Roques et al. 2009; Liebhold et al. 2012). Because wood and barkassociated insects comprise only a minor proportion of eucalypt insect pests that have been introduced into new areas (Figure 3), the introduction of wood products is probably not a major current pathway for the introduction of these insects. Live plant material and cut branches, however, provide a very viable possible pathway, considering that the majority of introductions have been foliage-feeding insects (Figure 3). Afforestation programmes are likely one of the major justifications for the import of live eucalypt plants (Wingfield et al. 2008). In New Zealand, untreated cut Eucalyptus foliage was imported from Australia until 1999, possibly contributing to the introduction of eucalypt pest 
introductions (Withers 2001). In South Africa, there are no known reports of imported live eucalypts and Eucalyptus branches used in floral arrangements are sourced locally, making these unlikely pathways of introduction. Paine et al. (2010), likewise considered live plant material an unlikely pathway for eucalypt pests in the USA because the production and sale of eucalypts was limited to those species already present in the country. It is thus not clear how so many pests that feed on foliage and that likely arrived with live plant material have entered new areas so frequently in recent decades.

There are various less obvious but plausible pathways for the introduction of insect pests outside those linked to commodities associated with the host plant. For example, insects have been intercepted at points of entry on camping equipment, containers, luggage/clothing of tourists or in used vehicles (Ridley et al. 2000; Withers 2001). The pet trade also poses a potential pathway of introduction. For example, in South Africa, eucalypt-feeding stick insects such as Extatosoma tiaratum have been imported from Australia for sale as pets (Kumschick et al., 2016; this issue), although no exotic establishments have been reported to date. It seems unlikely, however, that all the mentioned pests are accidental 'passengers' on other commodities or with people, and the movement of unrecorded or misidentified plant material could obscure pathways of movement in official trade records. Illegal introductions through smuggling plant material for propagation can clearly not be overlooked. The apparent lack of plausible pathways has also led some authors to suggest that intentional introductions or bioterrorism perpetrated by individuals or groups that oppose the planting of non-native trees might be to blame (Paine et al. 2010).

\section{Evolving responses to invasions}

One of the most important measures to deal with invasive insects feeding on eucalypts is to reduce the chances of their entry through quarantine. These measures include many components, but have typically attempted to ensure that traded products are free of specific pests, especially from areas of known infestation. This approach is very difficult to manage, given that many pests are unknown in their areas of origin before they have been introduced and because of the difficulty of monitoring the volume of goods traded. The focus in many cases has thus shifted to managing potential pathways of spread. For example, guidelines proposed under the International Standards for Phytosanitary Measures No. 15 (ISPM 15) require that wood and wood products are chemically (methyl bromide fumigation) or heat-treated before being exported to other regions to prevent the introduction of pests and pathogens (Haack et al. 2014). Recently, there has been a call for the regulation of imported live plant material, a more likely pathway for eucalypt insect pests than wood products (see above) (Liebhold et al. 2012; Roy et al. 2014) (Montesclaros Declaration: http://www.iufro.org/science/divisions/division7/700000/publications/montesclaros-declaration. However, even with such regulations in place, the immense volume of global trade makes the introduction of new pests almost inevitable (Brockerhoff et al. 2006b). In addition, although quarantine methods have become largely standardized between countries through organizations such as the International Plant Protection Convention (IPPC), the allocation of resources and implementation of these regulations is far from standardised, especially between developed and undeveloped economies (Bebber et al. 2014b). 
Despite the limitations of quarantine measures, these remain important for identifying and managing pathways of introduction and thus to at least reduce the numbers of new invasions. They also provide valuable interception data that can be used to predict likely future introductions (Brockerhoff et al. 2006a). This is especially the case for the introduction of insect pests of eucalypts, where confirmed pathways for most introductions are lacking. However, even when high-quality regulations are in place, the expectation of complete prevention of new introductions is unrealistic. Considerable investments will clearly be required in post-establishment population and spread management.

The application of insecticides, the release of biological control agents and the selection and deployment of resistant eucalypt genotypes have been the main strategies used to manage introduced insect pests of eucalypts. The use of insecticides has been limited due to the high costs required to apply these chemicals over a large area and also because of the increasing pressure from certification bodies such as the Forestry Stewardship Council (FSC), where increasing numbers of products are banned from use in certified forests (https://ic.fsc.org/pesticides.88.htm, accessed June 2015). These include chemicals such as cypermethrin that has been used to manage outbreaks of defoliating insects including Gonipterus spp. in the past. Most recently, the neonicitinoids acetamiprid and imadicloprid, which were considered as potential control measures for L. invasa and T. peregrinus (Noack et al. 2009; Zheng et al. 2014), have been added to FSC's banned list of insecticides. The move away from insecticides has placed increasing reliance on biological control and host resistance approaches to manage eucalypt pests.

Selection and planting of eucalypt species and genotypes resistant to insect pests has been a strategy used for some of the earliest pest introductions and remains one of the main responses to pest introductions. One of the first reported cases where this approach was applied is where eucalypt growers in South Africa replaced E. viminalis with other species due to its high susceptibility to Gonipterus sp., as well as the leaf pathogen Teratosphaeria (= Mycosphaerella) nubilosa (Tooke 1955; Hunter et al. 2008). More recently, there have been numerous trials to screen for resistance of current and potential commercial genotypes to the relatively new introductions of L. invasa (Pham Quang Thua et al. 2009; Javaregowda and Prabhu 2010; Nyeko et al. 2010; Dittrich-Schröder et al. 2012; Zheng et al. 2014) and O. maskelli (Protasov et al. 2007). In the case of L. invasa, the high level of susceptibility to E. grandis x camaldulensis clones in South Africa has led to a preference for planting E. grandis x urophylla hybrids in infested areas. However, insects can overcome plant resistance over time and new insects with different host preferences are likely to also be introduced. Thus, the strategy of deploying resistant genotypes will need to also evolve rapidly in order to respond quickly to these insect invasions. This includes maintaining a diversity of genotypes so that resistant genotypes can be quickly deployed should a commercial genotype become susceptible to a current or new pest. Genetic engineering and marker assisted breeding also offers promising avenues in this regard (Wingfield et al. 2013; Ledford 2014; Myburg et al. 2014).

Classical biological control is another strategy that has been used for some of the earliest introductions of eucalypt pests. The first reported successful introduction of a biological control agent for an insect pest of eucalypts was the introduction of the coccinellid Rhyzobius ventralis in New Zealand in 1908 for the control of Eriococcus coriaceus (Withers 2001). Other early cases of biological 
control include the introduction of egg parasitoids of Phoracantha spp. (first introduced 1910) (Webb 1974), Gonipterus spp. (1926) (Tooke 1955) and Paropsis charybdis (1934) (Withers 2001). Biological control agents have subsequently been released for a number of eucalypt pests (Withers 2001; Paine et al. 2011; Garnas et al. 2012). Recent releases include Cotesia urabae for the control of Uraba lugens (Avila et al. 2013), Cleruchoides noackae for Thaumastocoris peregrinus (Mutitu et al. 2013) and a number of parasitoid wasps for $L$. invasa (Mendel et al. 2004; Dittrich-Schröder et al. 2014; Zheng et al. 2014).

Despite past successes with classical biological control and its long-term benefits, the potential to use this approach to reduce the number of pest introductions is limited. This is in part due to the considerable time and financial investment required to implement biological control programmes (including costly and uncertain scouting trips to identify natural enemies in the native range), and the introduction of stricter regulations for the import of biological control agents (Hajek et al. 2016; this issue). In addition, for several species there is as yet no biological control available and for others the organisms introduced do no provide sufficient control, as with Gonipterus platensis by Anaphes nitens in the Iberian Peninsula (Reis et al. 2012). These challenges have led to increased and more formalized global collaboration between eucalypt growers to share knowledge and biological control agents (Garnas et al. 2012). An example of this is the recently formed programme BiCEP (Biological Control of Eucalyptus Pests, www.bicep.net.au), which aims to provide coordinated responses to invasive eucalypt pests through the use of biological control.

\section{Conclusions}

Eucalypts are one of the most widely planted tree species in the world. After many years of relative freedom from introduced herbivores, at least 42 insect species have now become established outside their native range of Australia, many in recent years. It is of great concern that the rate of their emergence in new areas has increased dramatically (nearly five times higher since the 1980's) in recent years. This is also despite a global realization of their potential negative impact and improved measures to avoid introductions and further spread.

Globally, the numbers of insect pests of eucalypts has doubled over the last three decades.

This means reduced yields, higher input costs, lost investments in breeding programs and a reduction in diversity of the range of planting stock that can be used. The accumulation in the number of pests clearly demands new management interventions. Apart from the increased rate of emergence outside their native range, the rate of intercontinental spread of pests is also increasing. Consequently it appears as if eucalypt plantation forestry should prepare for an increasingly globalized pool of pests, rather than strong regionally separated cohorts of pests. The elevated rate of establishment, very likely a consequence of ever-greater volumes of global trade and transport, is of particular concern in this regard.

Eucalypt pests are expected to continue to move around the world and increasing numbers of new pest invasions should be expected. This is because there is no evidence of change in the drivers of these introductions or spread of these pests. There are also no envisioned changes in legislation that 
might reduce their movement. A focus on efficient mitigation measures for an increasingly globalized pool of insect pests of eucalypts is clearly necessary for industries and governments globally. It should also be noted that the current number of insects established outside their native range represents only a very small proportion of the diversity present in the native range (Majer et al. 2000; Strauss 2001). It should be expected that some of the newly emerging invasions will likely be of species that are poorly studied or even not described in their native range, as has been the case with the detection of $L$. invasa in Israel (Mendel et al. 2004). In such cases, considerable resources will be required to acquire knowledge on the basic biology and ecology of the pest species in order to investigate management options. There is also an increasing number of insects native to the regions where eucalypts have been introduced that have expanded their host range to include eucalypt species, yet only a few of these have become serious pests (Gebeyehu et al. 2005; Wingfield et al. 2008; Paine et al. 2011; Degefu et al. 2012; Branco et al. 2015). Although there are currently no reports of the movement of these insects outside their native ranges, it is likely that, in time, some of these insects will spread to other eucalypt growing areas, including Australia (Paine et al. 2011).

The expansion of eucalypt planting has clearly facilitated the movement of eucalypt-feeding insects, but there is interestingly no clear association between the area planted to these trees and the number of established pests or first detections in new regions. Considering the global distribution of eucalypts and the substantial levels of interconnectedness between most areas with eucalypt plantings with regards to trade and travel, it is surprising that there are only a small number of first introduction points. A substantial barrier in understanding the patterns of invasion lies in the lack of confirmed pathways for these insects. This is an area that clearly requires urgent attention in order to implement pathway-management strategies and be able to better predict and plan for future introductions.

\section{Acknowledgments}

Members of the Tree Protection Cooperative Programme (TPCP), the National Research Foundation (NRF) and the Department of Trade and Industry (DTI) of South Africa, are acknowledged for their financial support. This paper had its origin at a workshop on "Drivers, impacts, mechanisms and adaptation in insect invasions” hosted by the DST-NRF Centre of Excellence for Invasion Biology in Stellenbosch, South Africa, in November 2014. DMR acknowledges support from the National Research Foundation (grant 85417).

\section{References}

Avila GA, Berndt LA, Holwell GI (2013) First releases and monitoring of the biological control agent Cotesia urabae Austin and Allen (Hymenoptera: Braconidae). N Z Entomol 36:65-72

Baker R, Cannon R, Bartlett P, Barker I (2005) Novel strategies for assessing and managing the risks posed by invasive alien species to global crop production and biodiversity. Ann Appl Biol 146:177-191

Bebber DP, Holmes T, Gurr SJ (2014a) The global spread of crop pests and pathogens. Global Ecol Biogeogr 23:1398-1407

Bebber DP, Holmes T, Smith D, Gurr SJ (2014b) Economic and physical determinants of the global distributions of crop pests and pathogens. New Phytol 202:901-910 
Borowiec N, Thaon M, Brancaccio L, Warot S, Ris N, Malausa J-C (2012) L'eucalyptus menacé par une nouvelle espèce d'Ophelimus en France. Phytoma 656:42-44

Branco M, Brockerhoff EG, Castagneyrol B, Orazio C, Jactel H, Saura S (2015) Host range expansion of native insects to exotic trees increases with area of introduction and the presence of congeneric native trees. J Appl Ecol 52:69-77

Brockerhoff EG, Bain J, Kimberley M, Knížek M (2006a) Interception frequency of exotic bark and ambrosia beetles (Coleoptera: Scolytinae) and relationship with establishment in New Zealand and worldwide. Can J For Res 36:289-298

Brockerhoff EG, Jactel H, Parrotta JA, Ferraz SFB (2013) Role of eucalypt and other planted forests in biodiversity conservation and the provision of biodiversity-related ecosystem services. For Ecol Manage 301:43-50

Brockerhoff EG, Liebhold AM, Jactel H (2006b) The ecology of forest insect invasions and advances in their management. Can J For Res 36:263-268

Close RC, Moar NT, Tomlinson AI, Lowe AD (1978) Aerial dispersal of biological material from Australia to New Zealand. Int J Biometeriology 22:1-19

Degefu D, Hurley BP, Garnas J, Wingfied MJ, Ahumada R, Slippers B (2012) Parallel host range expansion in two unrelated cossid moths infesting Eucalyptus nitens on two continents. Ecol Entomol 38:112-116

Dittrich-Schröder G, Harney M, Neser S, Joffe T, Bush S, Hurley BP, Wingfield MJ, Slippers B (2014) Biology and host preference of Selitrichodes neseri: A potential biological control agent of the Eucalyptus gall wasp, Leptocybe invasa. Biol Control 78:33-41

Dittrich-Schröder G, Wingfield MJ, Hurley BP, Slippers B (2012) Diversity in Eucalyptus susceptibility to the gall-forming wasp Leptocybe invasa. Agric For Entomol 14:419-427

Eldridge K, Davidson J, Harwood C, van Wyk G (1994) Eucalypt Domestication and Breeding. Oxford University Press, New York, United States

Essl F, Bacher S, Blackburn TM, Booy O, Brundu G, Brunel S, Cardoso A-C, Eschen R et al. (2015) Crossing frontiers in tackling pathways of biological invasions. Bioscience 65:769-782

FAO (2006) Global planted forests thematic study: results and analysis. In: Del Lungo A, Ball J, Carle J (eds) Planted Forests and Trees Working Paper, vol 38. Rome (also available at http://www.fao.org/forestry/site/10368/en),

FAO (2010) Global forest resources assessment 2010 - Main report. In: FAO Forestry Paper 163. Food and Agricultural Organization of the United Nations, Rome, Italy,

Farr JD, Dick SG, Williams MR, Wheeler IB (2000) Incidence of bullseye borer (Phoracantha acanthocera, Macleay) (Ceramybicidae) in 20-35 year old regrowth karri in the south west of Western Australia. Australian Forestry 63:107-123

Fisher MC, Henk DA, Briggs CJ, Brownstein JS, Madoff LC, McCraw SL, Gurr SJ (2012) Emerging fungal threats to animal, plant and ecosystem health. Nature 484:186-194

Flood J (2010) The importance of plant health to food security. Food Security 2:215-231

Fox KJ (1978) The transoceanic migration of Lepidoptera to New Zealand - a history and a hypothesis on colonisation. NZ Entomol 6:368-380

Garnas JR, Hurley BP, Slippers B, Wingfield MJ (2012) Biological control of forest plantation pests in an interconnected world requires greater international focus. Int J Pest Manage 58:211-223

Gebeyehu, Solomon, Hurley, Brett P, Wingfield, Michael J (2005) A new lepidopteran insect pest discovered on commercially grown Eucalyptus nitens in South Africa. S Afr J Sci 101:26-28

Grattapaglia D, Kirst M (2008) Eucalyptus applied genomics: from gene sequences to breeding tools. New Phytol 179:911-929

Haack RA (2006) Exotic bark- and wood-boring Coleoptera in the United States: recent establishments and interceptions. Can J For Res 36:269-288

Haack RA, Britton KO, Brockerhoff EG, Cavey JF, Garrett LJ, Kimberley M, Lowenstein F, Nuding A et al. (2014) Effectiveness of the International Phytosanitary Standard ISPM No. 15 on reducing wood borer infestation rates in wood packaging material entering the United States. PLoS One 9:e96611

Hulme PE (2006) Beyond control: wider implications for the management of biological invasions. J Appl Ecol 43:835-847

Hunter GC, Van Der Merwe NA, Burgess TI, Carnegie AJ, Wingfield BD, Crous PW, Wingfield MJ (2008) Global movement and population biology of Mycosphaerella nubilosa infecting leaves of cold-tolerant Eucalyptus globulus and E. nitens. Plant Pathol 57:235-242

Iglesias-Trabado G, Wilstermann D (2008) Eucalyptus universalis. Global cultivated eucalypt forests map 2008. GIT Forestry Consulting's EUCALYPTOLOGICS. http://www.git-forestry.com. 
Javaregowda J, Prabhu ST (2010) Susceptibility of Eucalyptus species and clones to gall wasp, Leptocybe invasa Fisher and La Salle (Eulophidae: Hymenoptera) in Karnataka. Karnataka J Agric Sci 23:220-221

Jeffries MJ, Lawton JH (1984) Enemy free space and the structure of ecological communities. Biol J Linn Soc 23:269-286

Keane RM, Crawley MJ (2002) Exotic plant invasions and the enemy release hypothesis. Trends Ecol Evol 17:164-170

Kenis M, Rabitsch W, Auger-Rozenberg MA, Roques A (2007) How can alien species inventories and interception data help us prevent insect invasions? Bull Entomol Res 97:489-502

Lawson S, Wylie FR, Wyile RL, Ryan P (2002) Longicorn beetles (Phoracantha spp.) and giant wood moths (Endoxyla spp.): Emerging threats in tropical and subtropical eucalypt plantations in Queensland, Australia vol 30.

Ledford H (2014) Brazil considers transgenic trees. Nature 512:357

Liebhold AM (2012) Forest pest management in a changing world. Int J Pest Manage 58:289-295

Liebhold AM, Brockerhoff EG, Garrett LJ, Parke JL, Britton KO (2012) Live plant imports: the major pathway for forest insect and pathogen invasions of the US. Front Ecol Environ 10:135-143

Lombaert E, Guillemaud T, Cornuet J-M, Malausa T, Facon B, Estoup A (2010) Bridgehead effect in the worldwide invasion of the biocontrol Harlequin ladybird. PLoS ONE 5:e9743

Majer JD, Recher HF, Ganesh S (2000) Diversity patterns of eucalypt canopy arthropods in eastern and western Australia. Ecol Entomol 25:295-306

Mapondera TS, Burgess T, Matsuki M, Oberprieler RG (2012) Identification and molecular phylogenetics of the cryptic species of the Gonipterus scutellatus complex (Coleoptera: Curculionidae: Gonipterini). Aust J Entomol 51:175-188

Mendel Z, Protasov A, Fisher N, La Salle J (2004) Taxonomy and biology of Leptocybe invasa gen. \& sp. n. (Hymenoptera: Eulophidae), an invasive gall inducer on Eucalyptus. Aust J Entomol 43:101-113

Mutitu EK, Garnas J, Hurley BP, Wingfied MJ, Harney M, Bush SJ, Slippers B (2013) Biology and rearing of Cleruchoides noackae (Hymenoptera: Mymaridae), an egg parasitoid for the biological control of Thaumastocoris peregrinus (Hemiptera: Thaumastocoridae). J Econ Entomol 106:1979-1985

Myburg AA, Grattapaglia D, Tuskan GA, Hellsten U, Hayes RD, Grimwood J, Jenkins J, Lindquist E et al. (2014) The genome of Eucalyptus grandis. Nature 510:356-362

Nahrung HF, Swain AJ (2015) Strangers in a strange land: do life history traits differ for alien and native colonisers of novel environments? Biol Invasions 17:699-709

Noack A, Kaapro J, Bartimote-Aufflick K, Mansfield S, Rose HA (2009) Efficacy of imidacloprid in the control of Thaumastocoris peregrinus on Eucalyptus scoparia in Sydney, Australia. Arboriculture and Urban Forestry 35:192-196

Nugnes F, Gebiola M, Monti MM, Gualtieri L, Giorgini M, Wang J, Bernardo U (2015) Genetic Diversity of the Invasive Gall Wasp Leptocybe invasa (Hymenoptera: Eulophidae) and of its Rickettsia Endosymbiont, and Associated Sex-Ratio Differences. PLoS One 10:e0124660

Nyeko P, Mutitu KE, Otieno BO, Ngae GN, Day RK (2010) Variations in Leptocybe invasa (Hymenoptera: Eulophidae) population intensity and infestation on eucalyptus germplasms in Uganda and Kenya. Int J Pest Manage 56:137-144

Olivier W (2010) There is honey in the forest: the history of forestry in South Africa. South African Institute of Forestry, Pretoria

Paine TD, Millar JG, Daane KM (2010) Accumulation of pest insects on Eucalyptus in California: Random process or smoking gun. J Econ Entomol 103:1943-1949

Paine TD, Steinbauer MJ, Lawson SA (2011) Native and exotic pests of Eucalyptus: a worldwide perspective. Annu Rev Entomol 56:181-201

Phạm Quang Thua, Bernard Dellb, Treena Isobel Burgessb (2009) Susceptibility of 18 eucalypt species to the gall wasp Leptocybe invasa in the nursery and young plantations in Vietnam. ScienceAsia 35:113-117

Pimental D, McNair S, Janecka J, Wightman J, Simmonds C, O'Connell C, Wong E, Russel L et al. (2001) Economic and environmental threats of alien plant, animal, and microbe invasions. Agric Ecosyst Environ 84:1-20

Protasov A, La Salle J, Blumberg D, Brand D, Saphir N, Assael F, Fisher N, Mendel Z (2007) Biology, revised taxonomy and impact on host plants of Ophelimus maskelli an invasive gall inducer on Eucalyptus spp. in the Mediterranean Area. Phytoparasitica 35:50-76

Reis AR, Ferreira L, Tomé M, Araujo C, Branco M (2012) Efficiency of biological control of Gonipterus platensis (Coleoptera: Curculionidae) by Anaphes nitens (Hymenoptera: 
Mymaridae) in cold areas of the Iberian Peninsula: Implications for defoliation and wood production in Eucalyptus globulus. For Ecol Manage 270:216-222

Rejmánek M, Richardson DM (2011) Eucalypts. In: Simberloff D, Rejmánek M (eds) Encyclopedia of Biological Invasions. University of California Press, Los Angeles, pp 203-209

Ridley GS, Bain J, Bulman LS, Dick MA, Kay MK (2000) Threats to New Zealand's indigenous forests from exotic pathogens and pests. vol 142. Department of Conservation, Wellington, NZ

Roques A, Rabitsch W, Rasplus J-Y, Lopez-Vaamonde C, Nentwig W, Kenis M (2009) Alien Terrestrial Invertebrates of Europe. In: DAISIE (ed) Handbook of Alien Species in Europe, vol 3. Invading Nature - Springer Series in Invasion Ecology. Springer Netherlands, pp 63-79

Roy BA, Alexander HM, Davidson J, Campbell FT, Burdon JJ, Sniezko R, Brasier C (2014) Increasing forest loss worldwide from invasive pests requires new trade regulations. Front Ecol Environ 12:457-465

Skarpaas O, Økland B (2009) Timber import and the risk of forest pest introductions. J Appl Ecol 46:55-63

Strauss SY (2001) Benefits and risks of biotic exchange between Eucalyptus plantations and native Australian forests. Austral Ecol 26:447-457

Tooke FGC (1955) The Eucalyptus snout beetle, Gonipterus scutellatus Gyll.: a study of its ecology and control by biological means. vol 3. Pretoria

Turnbull JW (1999) Eucalypt plantations. New Forests 17:37-52

Webb DvV (1974) Forest and Timber Entomology in the Republic of South Africa. Entomology Memoir No. 24. Department of Agricultural Technical Services, Republic of South Africa,

Wilson JRU, Dormontt EE, Prentis PJ, Lowe AJ, Richardson DM (2009) Something in the way you move: dispersal pathways affect invasion success. Trends Ecol Evol 24:136-144

Wingfield MJ (2003) Increasing threats of diseases to exotic plantation forests in the Southern Hemisphere: lessons from Cryphonectria canker. Australas Plant Path 32:133-139

Wingfield MJ, Roux J, Slippers B, Hurley BP, Garnas J, Myburg AA, Wingfield BD (2013) Established and new technologies reduce increasing pest and pathogen threats to Eucalypt plantations. For Ecol Manage 301:35-42

Wingfield MJ, Roux J, Wingfield BD (2011) Insect pests and pathogens of Australian acacias grown as non-natives - an experiment in biogeography with far-reaching consequences. Divers Distrib 17:968-977

Wingfield MJ, Slippers B, Hurley BP, Coutinho TA, Wingfield BD, Roux J (2008) Eucalypt pests and diseases: growing threats to plantation productivity. Southern For 70:139-144

Withers TM (2001) Colonization of eucalypts in New Zealand by Australian insects. Austal Ecology 26:467-476

Withers TM, Bain J (2009) Reducing rate of Australian Eucalyptus insects invading New Zealand. NZ Plant Protect 62:411

Wylie FR, Peters BC (1993) Insect pest problems of eucalypt plantations in Australia. 1. Queensland. Australian Forestry 56:358-362

Zheng XL, Li J, Yang ZD, Xian ZH, Wei JG, Lei CL, Wang XP, Lu W (2014) A review of invasive biology, prevalence and management of Leptocybe invasa Fisher \& La Salle (Hymenoptera: Eulophidae: Testrachinae). Afr Entomol 22:68-79 